\title{
Integrating Pyrolysis or Combustion with Scrubbing to Maximize the Nutrient and Energy Recovery from Municipal Sewage Sludge
}

\author{
Ali Saud ${ }^{1, *}{ }^{\mathbb{C}}$, Jouni Havukainen ${ }^{1}\left(\mathbb{D}\right.$, Petteri Peltola ${ }^{2}$ and Mika Horttanainen ${ }^{1}$ \\ 1 Department of Sustainability Science, Lappeenranta-Lahti University of Technology LUT, \\ 53850 Lappeenranta, Finland; Jouni.Havukainen@lut.fi (J.H.); Mika.Horttanainen@lut.fi (M.H.) \\ 2 Endev Ltd., Mannerheimintie 20 B, 00100 Helsinki, Finland; petteri.peltola@endev.fi \\ * Correspondence: ali.saud@lut.fi
}

\section{check for} updates

Citation: Saud, A.; Havukainen, J.; Peltola, P.; Horttanainen, M. Integrating Pyrolysis or Combustion with Scrubbing to Maximize the Nutrient and Energy Recovery from Municipal Sewage Sludge. Recycling 2021, 6, 52. https://doi.org/10.3390/ recycling 6030052

Academic Editors: Ismael

Leonardo Vera Puerto and Carlos

A. Arias

Received: 22 June 2021

Accepted: 31 July 2021

Published: 4 August 2021

Publisher's Note: MDPI stays neutral with regard to jurisdictional claims in published maps and institutional affiliations.

Copyright: (c) 2021 by the authors. Licensee MDPI, Basel, Switzerland. This article is an open access article distributed under the terms and conditions of the Creative Commons Attribution (CC BY) license (https:// creativecommons.org/licenses/by/ $4.0 /)$.
Abstract: Based on mass and energy balance calculations, this work investigates the possibility of recovering heat and nutrients (nitrogen and phosphorus) from municipal sewage sludge using pyrolysis or combustion in combination with a gas scrubbing technology. Considering a wastewater treatment plant (WWTP) with 65,000 t/a of mechanically dewatered digestate (29\% total solids), $550 \mathrm{t} / \mathrm{a}$ nitrogen and $500 \mathrm{t} / \mathrm{a}$ phosphorus were recovered from the $4900 \mathrm{t} / \mathrm{a}$ total nitrogen and $600 \mathrm{t} / \mathrm{a}$ total phosphorus that entered the WWTP. Overall, $3600 \mathrm{t} / \mathrm{a}(73 \%)$ of total nitrogen was lost to the air $\left(\right.$ as $\mathrm{N}_{2}$ ) and clean water, while $90 \mathrm{t} / \mathrm{a}(15 \%)$ of total phosphorus was lost to clean water released by the WWTP. Both in combustion and in pyrolysis, the nitrogen $(3 \%)$ released within thermal drying fumes was recovered through condensate stripping and subsequent gas scrubbing, and together with the recovery of nitrogen from WWTP reject water, a total of $3500 \mathrm{t} / \mathrm{a}$ of ammonium sulfate fertilizer can be produced. Furthermore, $120 \mathrm{GWh}$ /a of district heat and $9700 \mathrm{t} / \mathrm{a}$ of ash with $500 \mathrm{t} / \mathrm{a}$ phosphorus were obtained in the combustion scenario and 12,000 t/a of biochar with $500 \mathrm{t} / \mathrm{a}$ phosphorus was obtained in the pyrolysis scenario. The addition of a stripper and a scrubber for nitrogen recovery increases the total electricity consumption in both scenarios. According to an approximate cost estimation, combustion and pyrolysis require annual investment costs of 2-4 M EUR/a and 2-3 M EUR/a, respectively, while 3-5 M EUR/a and 3-3.5 M EUR/a will be generated as revenues from the products.

Keywords: combustion; energy recovery; nutrient recovery; pyrolysis; sewage sludge; thermal treatment; waste to energy

\section{Introduction}

The global population is estimated to increase from 7.7 billion to 9.7 billion by 2050 [1] This expected rapid increase, with the concentration of people in cities, raises several problems in terms of waste, particularly sewage sludge, which is the semi-solid byproduct generated during municipal and industrial wastewater treatment [2]. Billions of tons of sewage sludge and wastewater are produced every year, with the final disposal depending on the country's policies and regulations [3]. The current disposal pathways of sewage sludge in the EU include combustion (27\%), agricultural fertilizer (42\%), landfill (14\%), and other applications (17\%) [4].

Sewage sludge contains nutrients such as phosphorous and nitrogen [5]. However, it also contains harmful substances, including heavy metals, aromatic hydrocarbons, pathogens, and, as was recently discovered, microplastics and medical residues. Due to this fact, sewage sludge utilization as it is, and even after biological treatment, risks soil contamination [6].

Nutrients, mainly nitrogen and phosphorus, are crucial for the growth of plants and are thus in high demand, specifically as fertilizers [7]. About 75\% of the remaining phosphorus reserves are located in Morocco and, according to one estimate, these will 
be depleted within 45 to 100 years [8-10]. Phosphate, as a critical raw material, has received increased interest in the recovery and treatment of waste, specifically wastewater, to regenerate phosphorus using current technologies.

Nitrogen is a vital nutrient for all living organisms. While nitrogen is readily available in the atmosphere in the form of nitrogen gas $\left(\mathrm{N}_{2}\right)$, most plants cannot consume it due to the nonreactivity of molecular nitrogen. Some plants and crops use biological nitrogen fixation to absorb $\mathrm{N}_{2}$ in the form of ammonium or nitric oxide, but nitrogen fertilizers are needed to increase the crop yield [11].

The Haber-Bosch process was developed to transform stable $\mathrm{N}_{2}$ into nitrogen fertilizers to boost crop production [12]; however, producing 1 ton of ammonia $\left(\mathrm{NH}_{3}\right)$ fertilizer consumes about $35-50 \mathrm{MJ} / \mathrm{kgN}$ of energy and $950 \mathrm{~m}^{3}$ of natural gas, while emitting 1.6 tons of carbon dioxide $\left(\mathrm{CO}_{2}\right)$. However, only about $17 \%$ of the nitrogen produced in this way is ultimately consumed by humans through food sources, and the rest is lost to the environment [13]. This reactive nitrogen abundantly introduced to the ecosystem represents a significant source of pollution [14]. Although it has been possible to increase food production through the use of fertilizers, this has led to the disposal of nitrogen in the form of urea and $\mathrm{NH}^{4+}$ via human defecation, ending up in sewage [15]. This, in addition to other nitrogen leakages from crop production systems, such as the leaching of nitrogen from fields, causes eutrophication in water bodies [16].

A wastewater treatment plant (WWTP) is an industrial facility that removes pollutants through a series of operations, including the mechanical, chemical, and biological treatment of incoming wastewater. Wastewater treatment is an energy intensive process in which about $90 \%$ of total energy demand is in the form of electric energy. Furthermore, $50-60 \%$ of operating costs are taken by sludge treatment whereas electric energy takes a $25-40 \%$ share of total operating costs [4]. Therefore, efficient energy and nutrient recovery from a WWTP can lead to a better efficiency and reduced costs [17].

Nitrogen is first removed from an aeration tank via nitrification and denitrification, which convert ammonium and nitrate, respectively, into $\mathrm{N}_{2}$, releasing it into the atmosphere. The remaining nitrogen and phosphorus are bound in the sludge, which advances towards sludge treatment. Anaerobic digesters are one of the most common sludge treatment techniques, whereby the sludge is anaerobically digested to produce biogas, which is utilized in energy generation. The remnants of the process are mechanically dewatered, producing dried sludge and reject water [18].

The availability of organic matter in wastewater makes it an energy source from the thermodynamic perspective. After wastewater treatment, sewage sludge has an energy content of about $60 \%$ in the form of organic carbon, making it a potential energy source [19]. Moreover, sewage sludge is continuously generated during all stages in a WWTP. Sewage sludge contains organic pollutants, which can undergo thermochemical treatment while reducing the volume and producing energy. Combustion, pyrolysis, and gasification are three main thermochemical treatment methods, with the selection depending on the required temperature range and desired products. Figure 1 summarizes the thermal treatment options and their products.

In pyrolysis, the organic matter of sewage sludge is thermally degraded at high temperatures in the absence of oxygen. The products are bio-oil, biochar, and syngas. Biochar, which is also produced from biomass such as wood, is used mainly as a fuel, but it can also act as a low-cost adsorbent to remove pollutants in the form of pharmaceutical compounds, heavy metals, organic dyes, and phenolic compounds [20,21]. Ammonia inhibition and acid stress in microbes during anerobic digestion are reduced by increasing alkalinity and $\mathrm{pH}$ of solution which improves microbial colonization and results in increased yield of methane and digestate quality [22]. The yield of products depends on temperature, pressure, residence time, heating rate, sludge properties, and particle size. Pyrolysis is further classified in slow, fast, and flash pyrolysis. Slow pyrolysis uses temperatures ranging between 300 and $700{ }^{\circ} \mathrm{C}$ and a long residence time at a slow heating rate to maximize the yield of biochar [23]. In fast pyrolysis, the heating rate is $10-200^{\circ} \mathrm{C} / \mathrm{s}$ and the residence 
time is between 0.5 and $10 \mathrm{~s}$ to increase the yield of bio-oil. In flash pyrolysis, the heating rate is between $10^{3}$ and $10^{4} \mathrm{C} / \mathrm{s}$ and the residence time is less than $0.5 \mathrm{~s}$, with the bio-oil yield slightly higher than in fast pyrolysis [24].

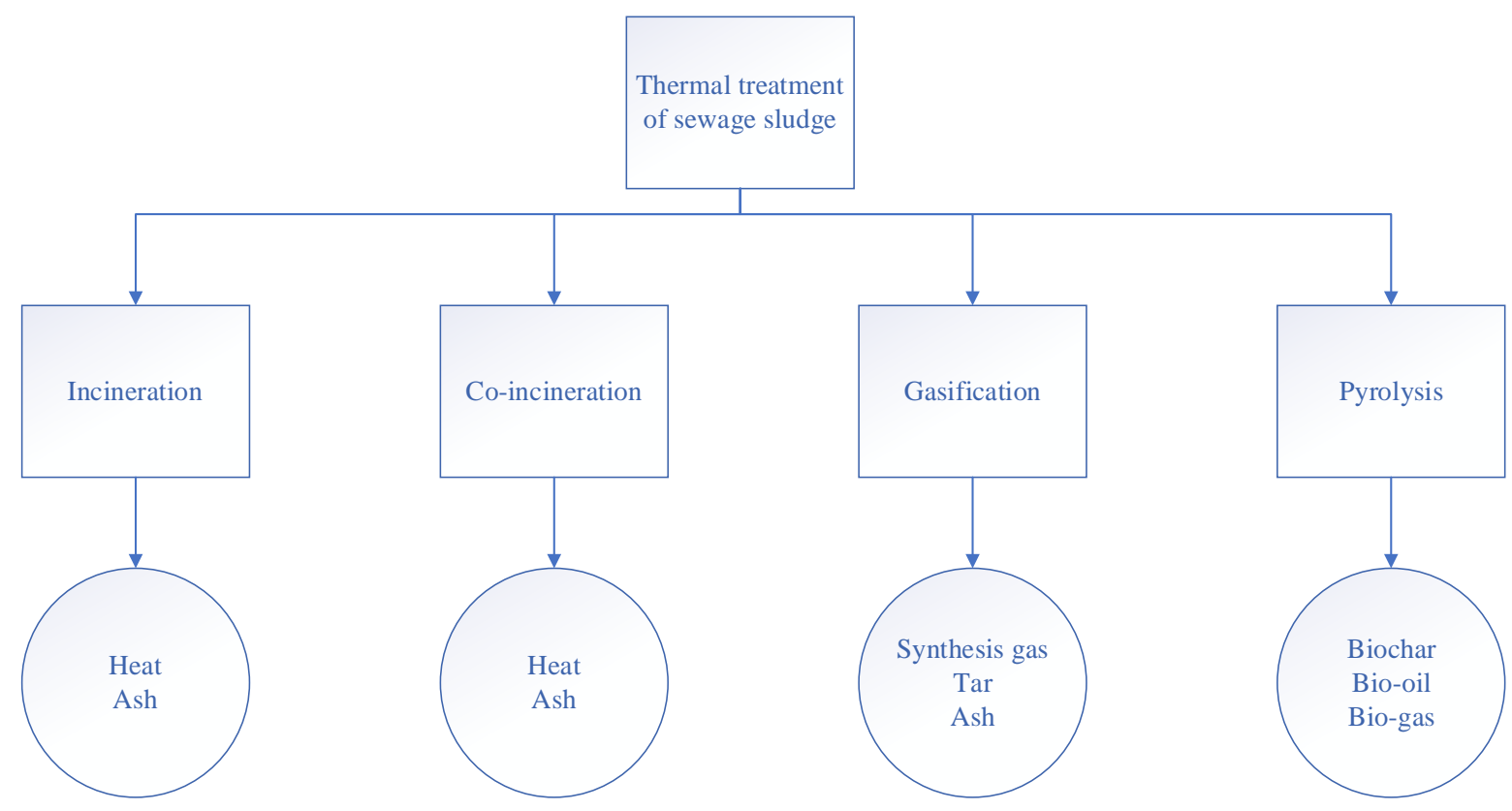

Figure 1. Sewage sludge thermal treatment classification.

In combustion, sewage sludge is thermally decomposed at elevated temperatures between 850 and $1300{ }^{\circ} \mathrm{C}$ [25], generating heat and electricity that can be utilized for several operations. Meanwhile, so-called bottom ash is extracted from the bottom of the furnace, and metals can be recovered, while the fly ash escaping with the flue gas can also be captured, e.g., by bag filters or wet scrubbers $[25,26]$. Gasification based on the partial oxidation of the organic solids produces synthesis gas that can be utilized for energy production; however, this process is not further described here as it is not considered as a treatment option.

Thermochemical treatment requires a lower moisture content, but the moisture content of sewage sludge is still $73-84 \%$ after mechanical dewatering [25,27]. A moisture content too high can decrease the combustion temperature, meaning that the EU Waste Incineration Directive's minimum required temperature of $850{ }^{\circ} \mathrm{C}$ is not met. The high amount of moisture further introduces complexities into the pyrolysis process, such as the formation of high-liquid products and an increase in non-condensable gases [28,29]. Thermal drying, usually utilizing heat from the combustion of the sludge or non-condensable (odorous) gases, offers a solution to reduce the sludge moisture content to 5-10\%, reducing the complexities and increasing the product quality $[25,30]$.

Previous research indicates that nitrogen recovery (instead of simple removal) is difficult to justify economically [31]. Hence, the efficiency should be improved, and possibilities should be found to at least decrease the costs of nitrogen capture. Single technical solutions, particularly for sludge or wastewater flow, are expensive compared to the yield and value of the utilizable product. Integrating nitrogen capture from more than one stream could improve the total recovery rate and make the investment less costly. For this reason, the current study focuses on the integration of pyrolysis or combustion with nitrogen recovery in the WWTP sludge treatment process to maximize the recovery of nutrients and energy for cases in which biological treatment is insufficient to remove harmful substances from the sludge. It also aims to evaluate the increase in the value and quality of products from sewage sludge by using mass and energy balance calculations and approximating the costs and revenues of each option. 


\section{Materials and Methods}

Two different sludge treatment and recovery processes currently being piloted in Finland, namely pyrolysis and combustion, are selected as the scenarios for analysis in this study. The pyrolysis-based process produces biochar, destined for use as an additive in composting. The other process is based on thermal drying and subsequent combustion of sludge, producing district heat and nutrient-rich (mainly $\mathrm{P}$ and $\mathrm{Ca}$ ) ash, which is used as forest fertilizer. Neither process currently incorporates nitrogen recovery in the pilot plants. In this study, comparability is achieved by using the same sludge input flow for both processes (although the pilot plants and WWTPs have very different sizes).

This study focuses on the following scenarios:

S1.0: Pyrolysis without N recovery.

S1.1: Pyrolysis with $\mathrm{N}$ recovery from thermal drying fumes but not from WWTP reject water.

S1.2: Pyrolysis with $\mathrm{N}$ recovery from both thermal drying fumes and WWTP reject water.

S2.0: Combustion without $\mathrm{N}$ recovery.

S2.1: Combustion with $\mathrm{N}$ recovery from thermal drying fumes but not from WWTP reject water.

S2.2: Combustion with $\mathrm{N}$ recovery from both thermal drying fumes and WWTP reject water.

Scenarios S1.0 and S2.0 are the base scenarios without the recovery of nitrogen. In the combustion base scenario, part of the fuel energy is recovered and utilized as district heat and the ash product is used as a forest fertilizer. The pyrolysis base scenario uses the sewage digestate in biochar production, and other pyrolysis products are combusted to produce the heat energy required for the thermal drying and pyrolysis process. The pyrolysis process additionally utilizes wood waste (to ensure energy self-sufficiency); in the combustion scenario, this waste is directed towards additional district heat production.

The technical data from the two pilot plants are used in this study. In the pyrolysis scenario, the sewage digestate obtained from the WWTP is pyrolyzed with wood (waste) to produce biochar. In the combustion scenario, the sewage sludge is combusted, and the excess energy is used for district heating. The comparison between the different technologies is enabled by applying the technical performance values for the common sludge mass flow, namely the sludge mass flow of the Viikinmäki WWTP in Helsinki, operated by Helsinki Region Environmental Services (HSY).

\subsection{Wastewater Treatment Plant, Sludge Digestion, and Dewatering}

In the WWTP plant, wastewater enters with a flow rate of $92 \times 10^{6} \mathrm{~m}^{3} /$ a with $29 \times 10^{6} \mathrm{~kg} /$ a total solids (TS). The plant potentiality in terms of population equivalent is $3 \mathrm{~m}^{3}$ /day/person. Nitrogen and phosphorus are the two primary nutrients, with mass flow rates of $4900 \mathrm{t} / \mathrm{a}$ and $600 \mathrm{t} / \mathrm{a}$, respectively. After the wastewater treatment processes of pre-treatment, screening, and aeration, the raw sludge enters anaerobic digestion, resulting in biogas and digestate. The biogas is used for heat and electricity production, whereas the remaining digestate goes to dewatering. The amount of reject water is calculated based on the difference in the mass of the digestate and dewatered sludge.

The total energy consumption of the WWTP is $0.42 \mathrm{kWh} / \mathrm{m}^{3}$. After anaerobic digestion, the sewage sludge has a $95 \%$ moisture content, and sequential moisture removal processes are key to thermally treating sludge. Thermal drying is an energy-intensive process; therefore, dewatering is performed beforehand to reduce the energy consumption [25]. Dewatering of the digestate helps to reduce the volume of the sludge by removing water, simplifying transport, and increasing the calorific value [32]. The pyrolysis of wet digestate generates steam in the reactor, leading to either a higher moisture content in the product or a high production of non-condensable gases. Furthermore, the combustion of high-moisture digestate would not achieve the temperature levels required by waste combustion legislation. Therefore, sewage sludge undergoes mechanical dewatering and thermal drying to reduce the moisture content to $65 \%$ and $5 \%$, respectively [33].

Nutrients, mainly nitrogen, are still available for recovery in the reject water as well as the thermal drying fumes, which are directed to the condenser, with the resulting 
condensate containing nitrogen. Mass balance calculations are conducted for both dewatering and thermal drying, whereby nitrogen is the key focus in all phases. The nitrogen share in the reject water is about $16 \%$ of the total nitrogen contained in the wastewater, which is within the 10-30\% range reported in previous studies [34]. In thermal drying, the target moisture removal is $80 \%$ [30]. Saud et al. [31] and Deviatkin et al. [30] investigated nitrogen recovery from thermal drying of sewage sludge using established scrubber technology. The mass balance for the WWTP and the dewatering and thermal drying processes is presented in Table 1; a more detailed mass balance is given in the Table S2 of the Supplementary Materialss.

Table 1. Mass balance for the WWTP considered in this study [35].

\begin{tabular}{lll}
\hline WWTP & Value & Unit \\
\hline Wastewater & 250,000 & $\mathrm{~m}^{3} / \mathrm{d}$ \\
Nitrogen & 13 & $\mathrm{t} / \mathrm{d}$ \\
Phosphorus & 1.6 & $\mathrm{t} / \mathrm{d}$ \\
TS & 79 & $\mathrm{t} / \mathrm{d}$ \\
Clean water & & \\
Mass & 250,000 & $\mathrm{t} / \mathrm{d}$ \\
Nitrogen & 1.2 & $\mathrm{t} / \mathrm{d}$ \\
Phosphorus & 0.041 & $\mathrm{t} / \mathrm{d}$ \\
Mass to digestion & & \\
Mass & 2600 & $\mathrm{t} / \mathrm{d}$ \\
TS & 88 & $\mathrm{t} / \mathrm{d}$ \\
Nitrogen & 3.6 & $\mathrm{t} / \mathrm{d}$ \\
Phosphorus & 1.4 & $\mathrm{t} / \mathrm{d}$ \\
Dewatered digestate & & \\
Mass & 180 & $\mathrm{t} / \mathrm{d}$ \\
TS & 52 & $\mathrm{t} / \mathrm{d}$ \\
Nitrogen & 1.5 & $\mathrm{t} / \mathrm{d}$ \\
Phosphorus & 1.4 & $\mathrm{t} / \mathrm{d}$ \\
Reject water & & \\
Mass & 2400 & $\mathrm{t} / \mathrm{d}$ \\
TS & 1.1 & $\mathrm{t} / \mathrm{d}$ \\
Nitrogen & 2.1 & $\mathrm{t} / \mathrm{d}$ \\
Phosphorus & 0.033 & $\mathrm{t} / \mathrm{d}$ \\
Thermally dried digestate & & $\mathrm{t}$ \\
Mass & 58 & $\mathrm{t}$ \\
TS & 52 & $\mathrm{t} / \mathrm{d}$ \\
Moisture content & 20 & $\mathrm{t} / \mathrm{d}$ \\
Nitrogen in drying fumes & 0.74 & \\
Condensate & 120 & \\
Mass & 0.47 & \\
Nitrogen & & \\
\hline & & \\
\hline
\end{tabular}

\subsection{Pyrolysis Scenario}

In the pyrolysis scenario, presented in Figure 2, wood waste is used together with digestate to produce biochar and pyrolysis gas. The digestate constitutes $70 \%$ of the pyrolyzed mass, and the remaining 30\% is wood waste. The reason for adding wood waste is to compensate for the lower heating value of the digestate and to introduce more carbon. The pyrolysis process is assumed to be self-sufficient in terms of heat energy through the combustion of the pyrolysis gas and recovering the heat to be used for both thermal drying and pyrolysis. The electricity consumption of the thermal drying process is $0.45 \mathrm{kWh} / \mathrm{kg}$ [36], whereas that of the pyrolysis process is another $0.01 \mathrm{kWh} / \mathrm{kg}$ [35]. The mass balance of the pyrolysis process is summarized in Table 2 . 


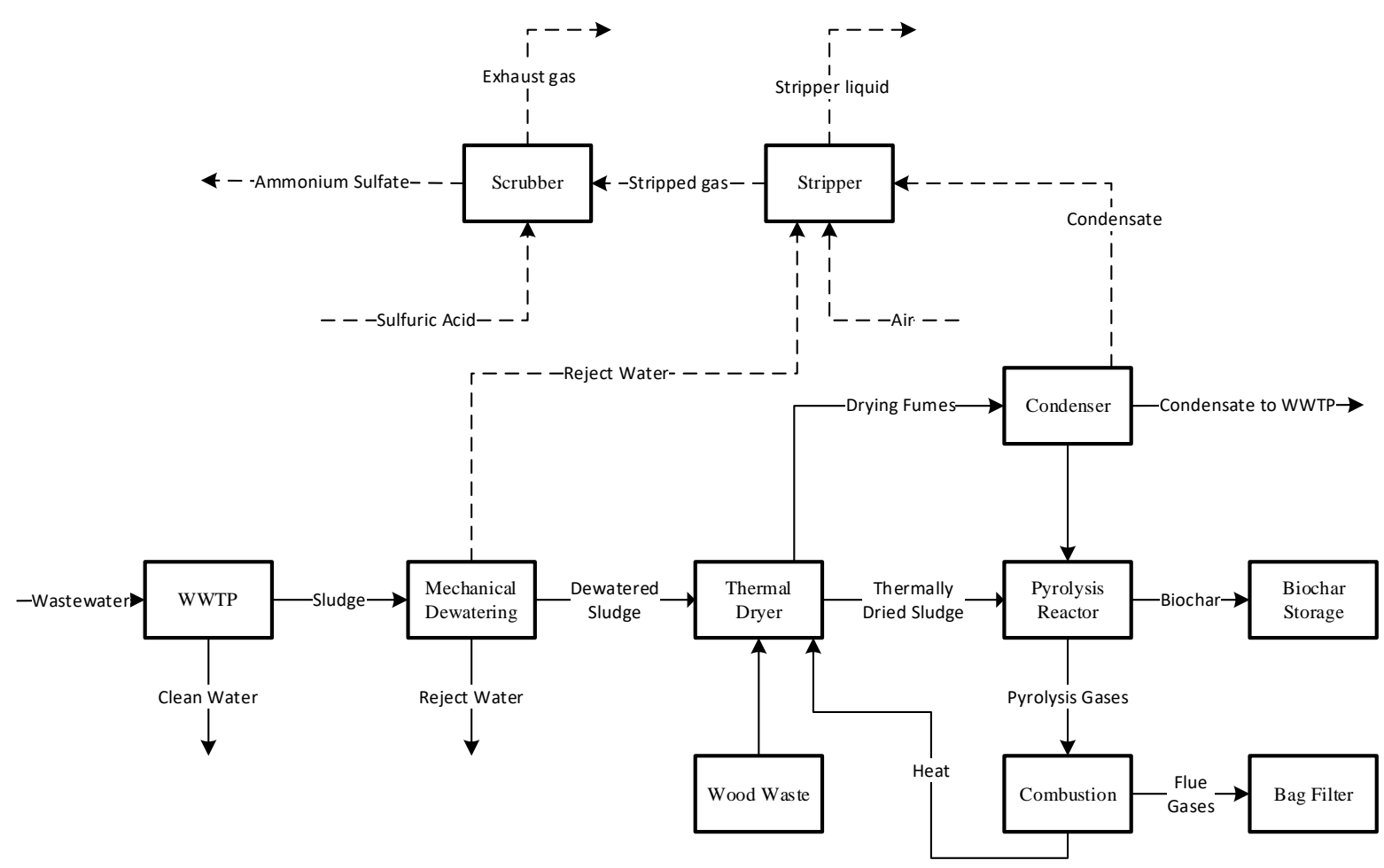

Figure 2. Block diagram of the pyrolysis process. Solid lines denote the current process and dotted lines show the possibilities to recover nitrogen from the reject water and thermal drying fumes.

\subsection{Combustion Scenario}

The sludge combustion data are taken from a novel sludge combustion plant, sited in Rovaniemi (Finland) and built by Endev Ltd., which has a throughput of 10,000 t/a. After mechanical dewatering in the WWTP, the sludge enters an integrated fluidized bed drying and combustion process (Figure 3). First, hot sand from a combustion reactor is mixed with the sludge in a dryer to remove moisture, thereby increasing the dry solids content of the sludge to $95-98 \mathrm{wt} \%$. Then, the dried sludge is transferred to a fluidized bed reactor for combustion. The temperature of the reactor is maintained at $850^{\circ} \mathrm{C}$ to ensure the destruction of organic pollutants (pathogens, drug residuals, microplastics, etc.). The ash formed in the combustion is carried with flue gases and extracted at two points: the majority of the ash ( $>95 \mathrm{wt} \%)$, the so-called product ash, is collected through a high-temperature cyclone after the air preheater, while the finer ash is removed by a bag filter as byproduct ash. The heat produced in the combustion is used in thermal drying and district heating, whereas the hygienic and nutrient-rich product ash can be used as fertilizer. The water vapor from the fluidized bed dryer is sent to a condenser, and the condensate is directed to the WWTP for wastewater treatment. This condensate contains recoverable nitrogen with concentrations up to $3000 \mathrm{mg} / \mathrm{L}$. The electricity consumption of the combustion plant is $0.147 \mathrm{kWh} / \mathrm{t}$ of dewatered sludge, and the thermal efficiency of the plant is $82 \%$.

A wood boiler is also added to the process to make the mass and energy balance comparable with the pyrolysis scenario. The lower heating value (as-received basis) of thermally dried digestate and wood waste is calculated using Equation (1).

$$
\mathrm{LHV}_{\mathrm{ar}}=\operatorname{LHV}_{\mathrm{dry}} \times(1-w)-l_{25} w
$$

where the lower heating value for total solids $\left(\mathrm{LHV}_{\mathrm{dry}, \mathrm{D}}\right)$ is $13 \mathrm{MJ} / \mathrm{kg}$ for thermally dried digestate and $18 \mathrm{MJ} / \mathrm{kg}$ for wood $\left(\mathrm{LHV}_{\mathrm{dry}, \mathrm{W}}\right)$. Furthermore, the moisture content, $w$, is $5 \%$ for thermally dried digestate and $41 \%$ for wood waste, and the heat of vaporization of water, $l_{25}$, is $2.443 \mathrm{MJ} / \mathrm{kg}$. As a result, the lower heating value as received, $\mathrm{LHV}_{\mathrm{ar}, \mathrm{D}}$ of thermally dried digestate is $12 \mathrm{MJ} / \mathrm{kg}$, and the $\mathrm{LHV}_{\mathrm{ar}, \mathrm{W}}$ of wood is $9.6 \mathrm{MJ} / \mathrm{kg}$. 


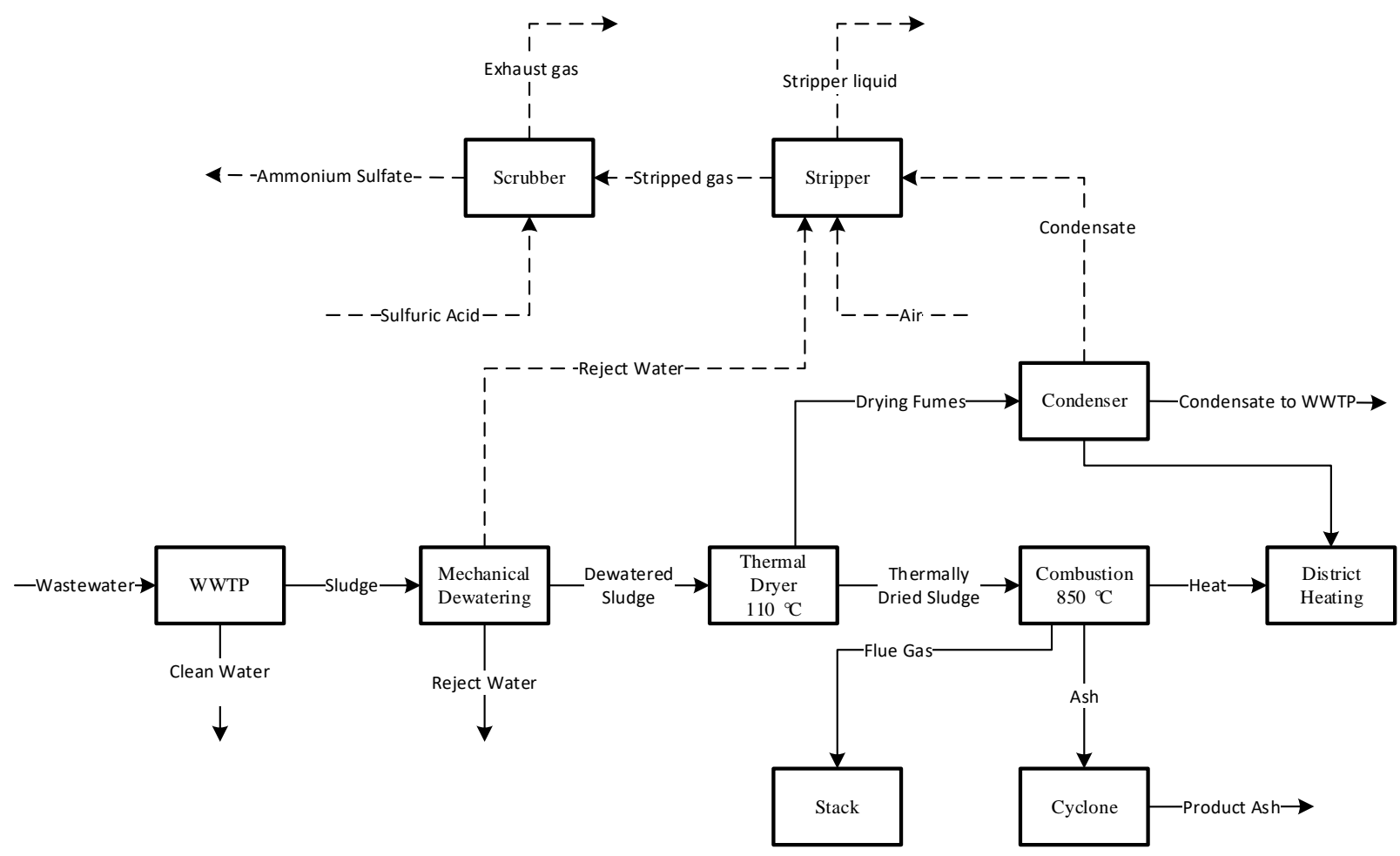

Figure 3. Block diagram of the combustion process. Solid lines denote the current process and dotted lines show the possibilities to recover nitrogen from the reject water and thermal drying fumes.

\subsection{Recovery of Nutrients}

In both the pyrolysis and combustion scenarios, $780 \mathrm{t} / \mathrm{a}$ of nitrogen ends up in the reject water and can be recovered by adding a stripper and a gas scrubber to the systems. Furthermore, it is assumed, based on Horttanainen et al. [37], that $12 \%$ of the total nitrogen in the dewatered sludge is released in the thermal drying fumes in the form of $\mathrm{NH}_{3}$. The high moisture content of the drying fumes would result in a diluted fertilizer. To avoid this, a condenser is added to the process before the stripper-scrubber combination, and thus the drying fumes first pass through this condenser; the condensate is directed to the stripper-scrubber combination together with the reject water.

Air is used to separate gaseous ammonia $\left(\mathrm{NH}_{3}\right)$ from the liquid in the column in the stripping process. This study assumes a stripping column efficiency of $95 \%$ based on the previous literature $[38,39]$. Subsequently, the stripped gas is directed to an acid scrubber to capture ammonia using sulfuric acid to produce ammonium sulfate. In the scrubber, the liquid to gas $(\mathrm{L} / \mathrm{G})$ ratio, acid $\mathrm{pH}$, and mass transfer area play significant roles $[31,40]$. The scrubber efficiency is also assumed to be $95 \%$ based on previous studies [41,42]. The exhaust gas from the scrubber is directed to combustion to destroy possible odorous compounds.

\subsection{Cost Estimation}

The general cost estimation is conducted based on sewage sludge-derived biochar and district heat prices in Finland. Table 2 takes only the sewage sludge-derived biochar values into account in the calculation of the total investment cost. However, other wood-derived biochar values are presented to enable a comparison of the prices with sewage sludgederived biochar. There is a high variation in the district heat prices due to differences in regional transmission and supply and demand. Therefore, an average of all values is considered to calculate the revenue from district heating. All district heating prices are exclusive of value-added taxes (VAT). 
Table 2. Biochar and district heat revenue estimation in the pyrolysis and combustion scenarios.

\begin{tabular}{ccc}
\hline Biochar $(\mathbf{S 1 . 1}$ and S1.2) & & \\
\hline Price $($ EUR/t) & Country & Reference \\
Sewage sludge derived & Finland & {$[43]$} \\
0 & Finland & {$[43]$} \\
400 & & \\
Wood derived & Finland & {$[44]$} \\
700 & USA & {$[45]$} \\
800 & & \\
District heat $(\mathbf{S} 2.1$ and $\mathbf{S 2 . 2})$ & Country & Reference \\
Price (EUR/MWh) & Finland & {$[46]$} \\
40 & Finland & {$[47]$} \\
50 & Finland & {$[48]$} \\
60 & Finland & {$[49]$} \\
62 & Finland & {$[46]$} \\
\hline
\end{tabular}

\section{Results and Discussion}

\subsection{Recovery of Nitrogen from Drying Fumes}

The results of the pyrolysis and combustion scenarios with and without the recovery of nitrogen from the reject water are shown in Figures 4-9. Figures 4 and 5 present the base scenarios S1.0 (pyrolysis without N recovery) and S2.0 (combustion without $\mathrm{N}$ recovery), respectively. In both scenarios, it is evident that nitrogen could be recovered from the drying fumes and reject water.

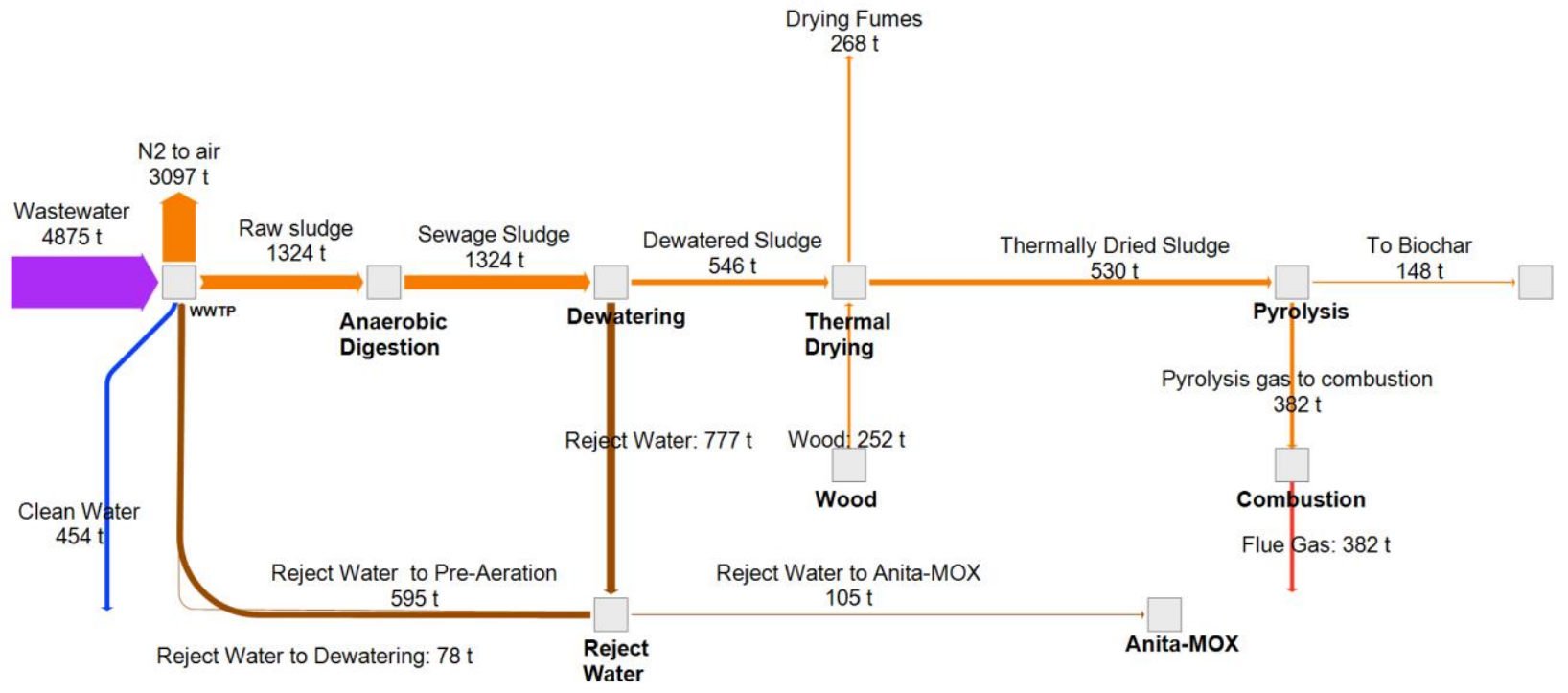

Figure 4. Nitrogen balance for S1.0 (pyrolysis base scenario, no $\mathrm{N}$ recovery).

The pyrolysis scenario S1.1 and combustion scenario S2.1, where nitrogen is recovered from the drying fumes but not from the reject water, are presented in Figures 6 and 7, respectively. The mass balance calculations reveal that the nitrogen loss in the WWTP process is $3100 \mathrm{t} / \mathrm{a}$ in the form of $\mathrm{N}_{2}$ to the atmosphere and $450 \mathrm{t} / \mathrm{a}$ in the form of nitrate $\left(-\mathrm{NO}_{3}\right)$ and ammonium ions $\left(\mathrm{NH}^{4+}\right)$ to clean water, estimated as a $73 \%$ loss of total nitrogen. The remaining nitrogen ends up in dewatered digestate, calculated at $550 \mathrm{t} / \mathrm{a}$, or $11 \%$. The remaining $16 \%$, or $780 \mathrm{t} / \mathrm{a}$, is present mainly in the reject water from the mechanical dewatering and can be recovered. Similarly, it is calculated that $3 \%$ of nitrogen can be recovered from the drying fumes. The drying fumes from the thermal dryer contain $160 \mathrm{t} / \mathrm{a}$ of nitrogen, capable of producing ammonium sulfate fertilizer. The condenser offers two benefits: firstly, it removes moisture from the non-condensable odorous gases that enter 
the combustion process. Secondly, it recovers nitrogen from the condensed water. In this case, assuming a scrubber efficiency of $95 \%, 160 \mathrm{t} / \mathrm{a}$ of nitrogen can be captured for use as fertilizer. Odorous gases are directed to combustion. In Figure 5, the combustion of sewage sludge produces $120,000 \mathrm{MWh}$ / a of heat, which can be used for district heating, as explained in a later section. Thermally dried sludge still contains $400 \mathrm{t} / \mathrm{a}$ of nitrogen, which is eventually combusted and cannot be utilized. Phosphorus ends up in the ash of sewage sludge combustion. A more detailed nutrient balance is presented in the Tables S4-S6 in the Supplementary Materials. Almost $95 \%$ of the phosphorus in thermally dried sewage sludge ends up in the product ash, with the remaining $5 \%$ contained in the non-utilizable byproduct ash [50].

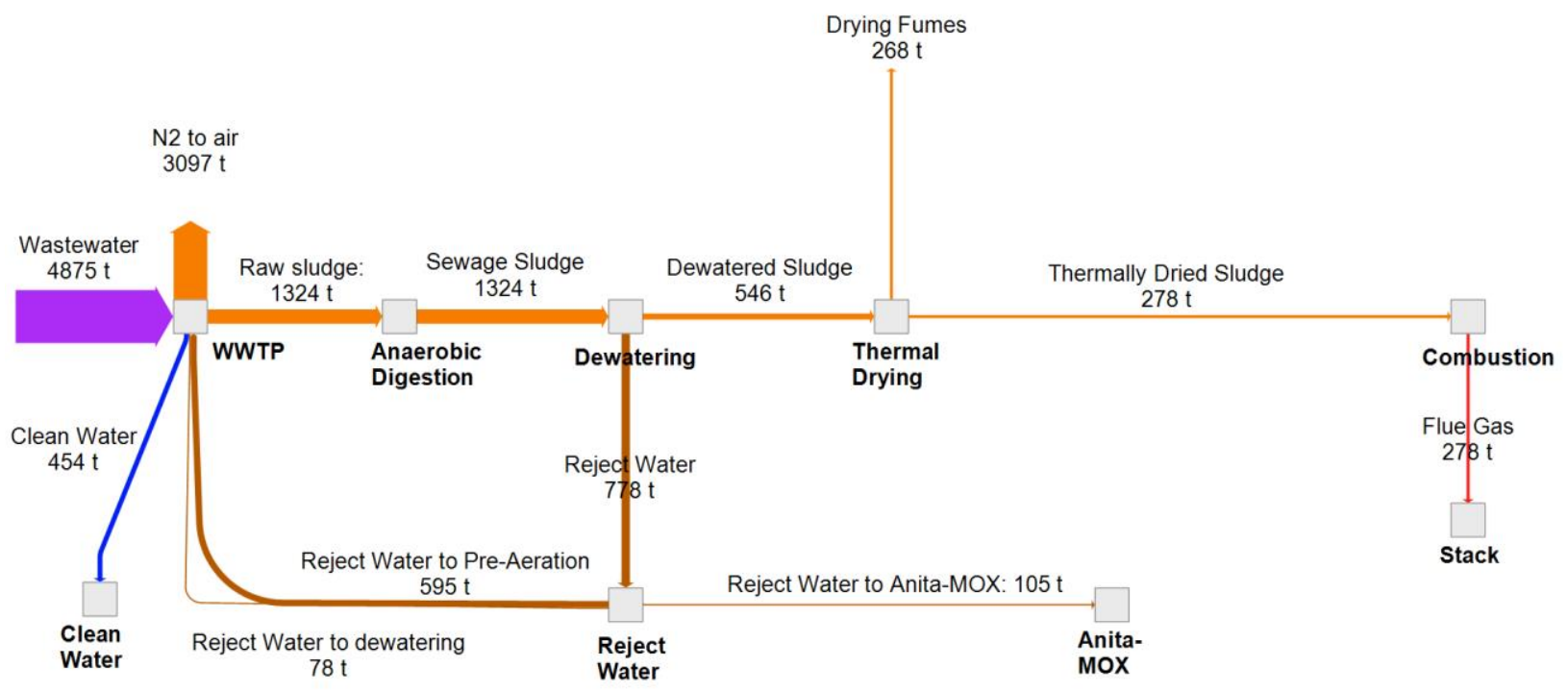

Figure 5. Nitrogen balance for S2.0 (combustion base scenario, no N recovery).

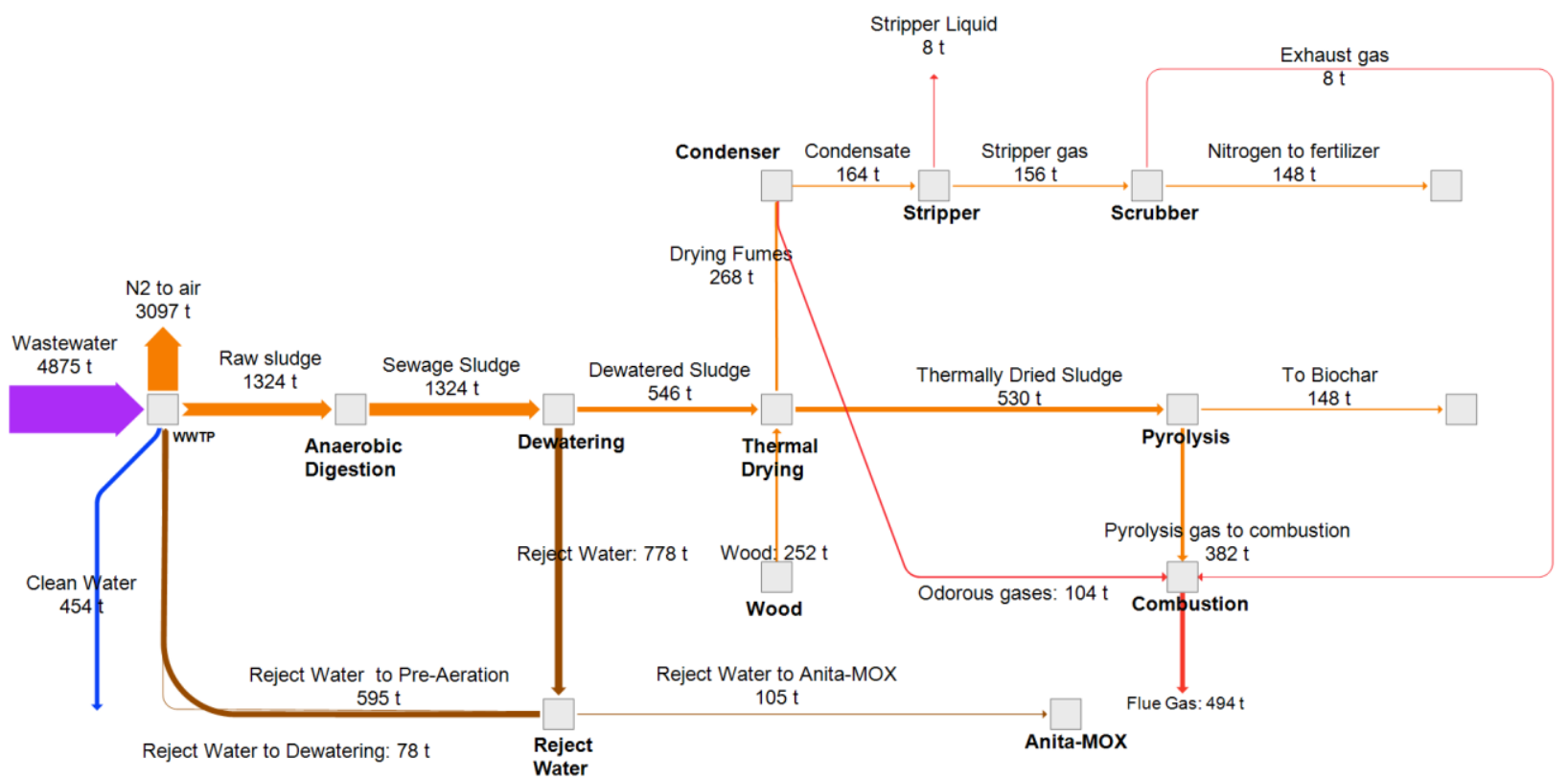

Figure 6. Nitrogen balance for S1.1 (pyrolysis with $\mathrm{N}$ recovery from drying fumes). 


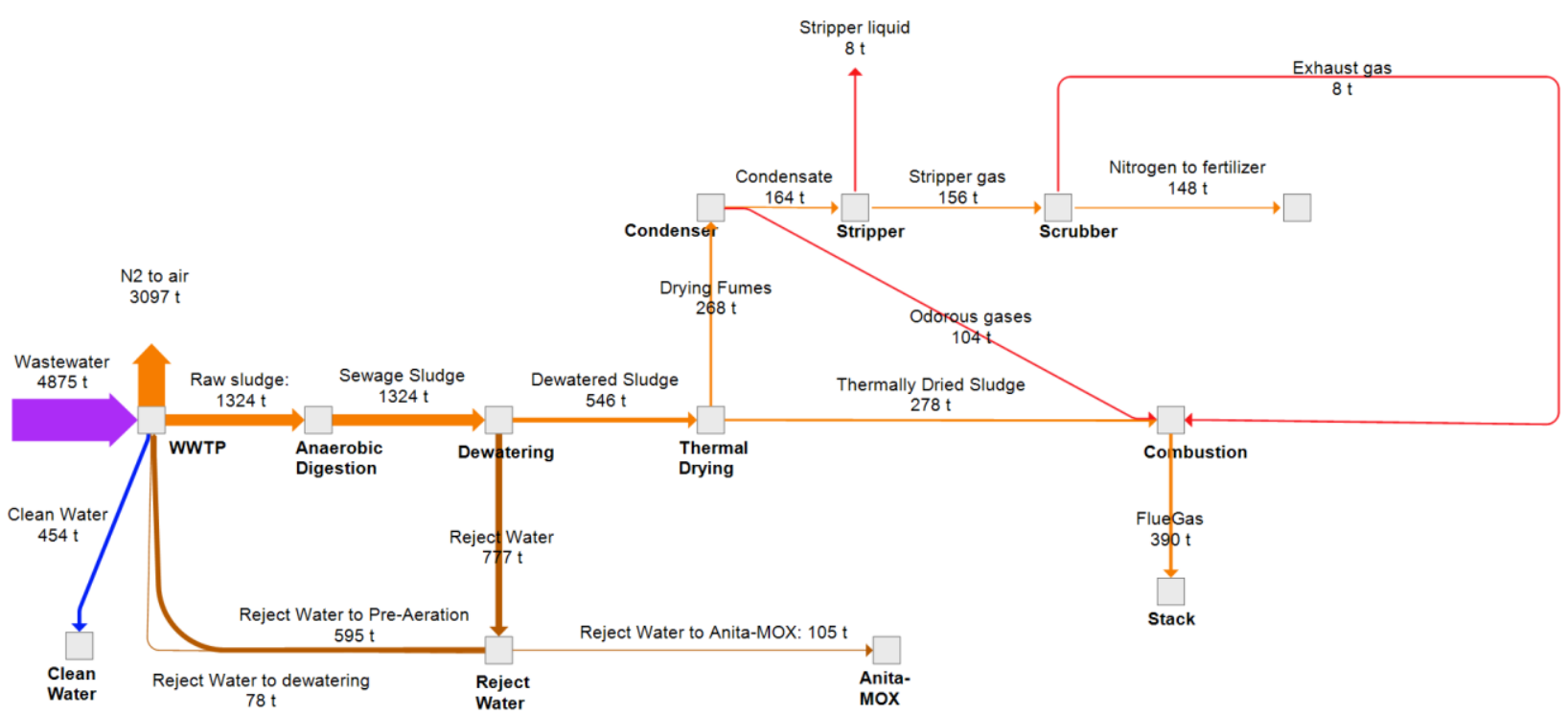

Figure 7. Nitrogen balance for S2.1 (combustion with N recovery from drying fumes).

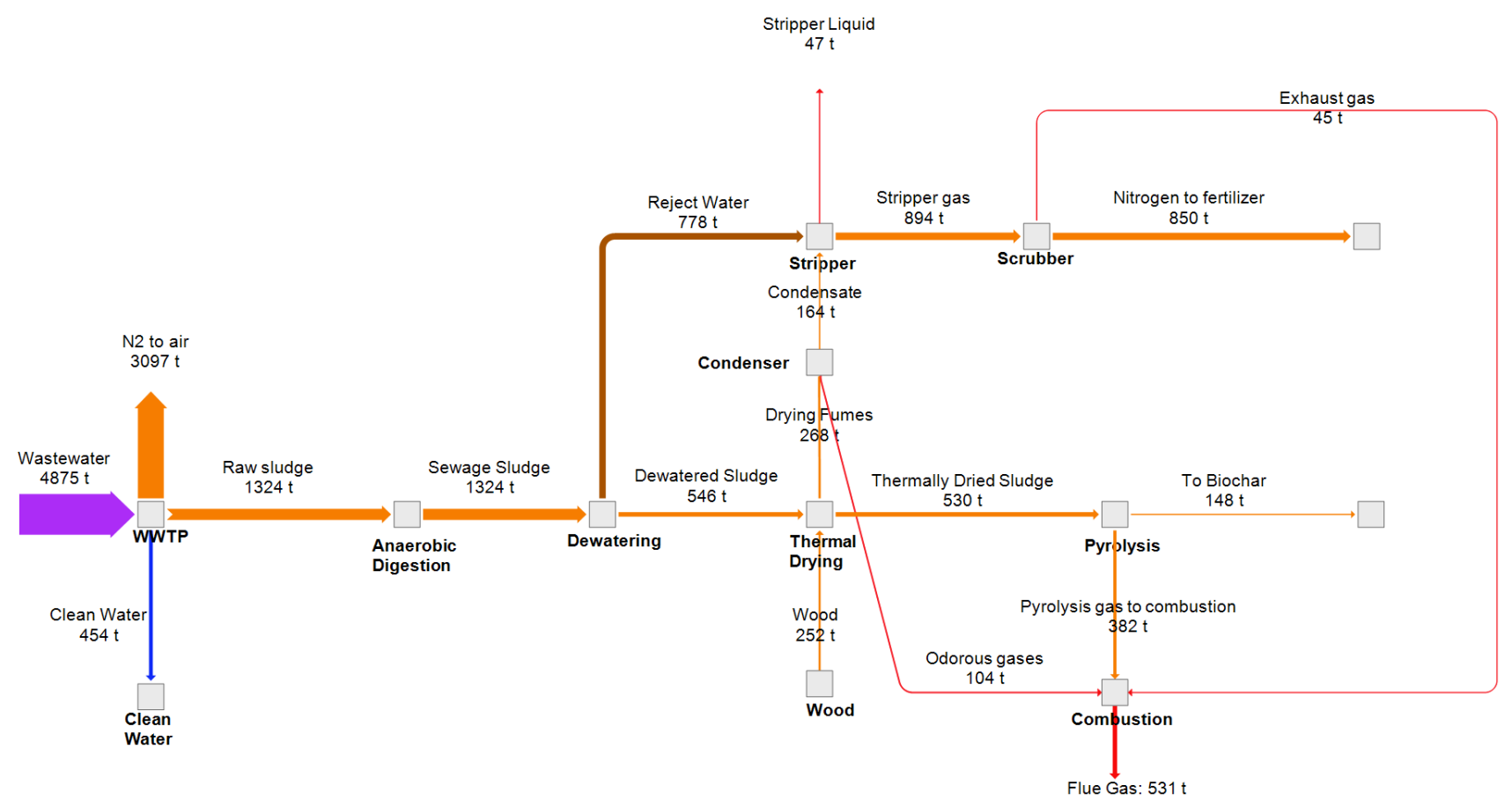

Figure 8. Nitrogen balance for S1.2 (pyrolysis with $\mathrm{N}$ recovery from drying fumes and reject water).

As shown in Figure 4, 12,000 t/a of biochar, as the main product, contains about $150 \mathrm{t} / \mathrm{a}$ nitrogen, and $150 \mathrm{t} / \mathrm{a}$ of ammonium fertilizer can be produced in the scrubber as part of the pyrolysis process. The biochar also includes $500 \mathrm{t} / \mathrm{a}$ of phosphorus. This biochar has commercial value as a soil amendment and fertilizer due to the presence of nutrients such as phosphorus and nitrogen, although it may be in a less available form for plants [51]. The gases produced during pyrolysis are used for heating in the main plant equipment, such as the pyrolysis reactor and dryer.

\subsection{Recovery of Nitrogen from Reject Water}

Only a small amount of nitrogen ( $268 \mathrm{t} / \mathrm{a})$ is available for recovery in the thermal drying fumes. It is difficult to justify the investment needed to conduct this recovery alone as the off-gases are irrespectively treated during combustion, whereby the ammonia can 
be converted to $\mathrm{N}_{2}$. To increase the overall feasibility of nitrogen recovery, it is possible to combine the recovery from thermal drying fumes with recovery from WWTP reject water, which contains the majority of recoverable nitrogen. In the WWTP reject water, $780 \mathrm{t} / \mathrm{a}$ of nitrogen is available for recovery and further utilization as ammonium fertilizer as shown in Figures 8 and 9.

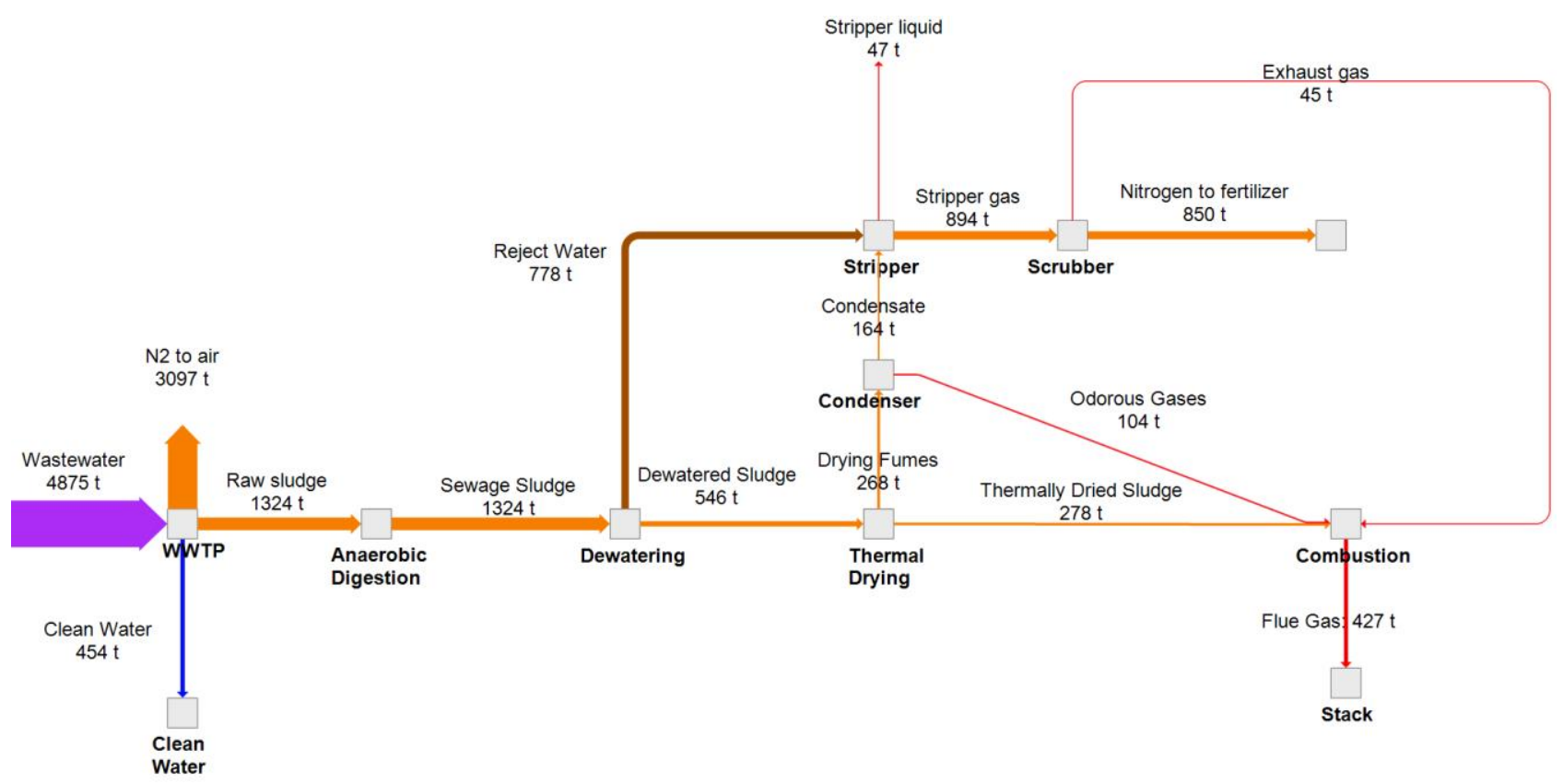

Figure 9. Nitrogen balance for S2.2 (combustion with N recovery from drying fumes and reject water).

\subsection{Comparison of Mass and Energy Balances}

The mass balances of the pyrolysis and combustion scenarios (Table 3) use the same amount of wastewater input, and the difference is in the end-products' masses. As shown in Table 3, biochar is produced in pyrolysis at a mass of 12,000 $\mathrm{t}$ without ash production, while the combustion process produces $9700 \mathrm{t}$ of ash as a byproduct along with district heat, including $1600 \mathrm{t}$ of wood ash. More than $95 \%$ of the ash is separated by a cyclone at a high temperature to reduce the heavy metal concentration. The resulting ash contains phosphorus and can be used in forestry or agriculture, although only $10-25 \mathrm{wt} \%$ is available in the form of $\mathrm{P}_{2} \mathrm{O}_{5}$ compared to the $5-40 \mathrm{wt} \%$ of $\mathrm{P}_{2} \mathrm{O}_{5}$ in phosphate ores. The ash can also be used to manufacture lightweight bricks and tiles, as an additive in the manufacture of cement, and as a raw material for Portland cement [52]. Meanwhile, biochar can be used as an adsorbent to remove heavy metals and pollutants from aqueous solutions [53] and as a soil amendment [54]. The heavy metals in biochar and other hazardous compounds, such as dissolved organic carbon which might end up in soil and drinking water after leaching or rainfalls, are still a concern in applicability of biochar in soil. The potential risk of heavy metals in sewage sludge can be reduced by pyrolysis with variation of temperature [55]. The increase in temperature from 300 to $700{ }^{\circ} \mathrm{C}$, increase the concentration of zinc ( $\left.\mathrm{Zn}\right)$, chromium $(\mathrm{Cr})$, nickel $(\mathrm{Ni})$, and copper $(\mathrm{Cu})$, whereas the concentration of lead $(\mathrm{Pb})$ and cadmium $(\mathrm{Cd})$ is decreased when temperature increases from 600 to $700{ }^{\circ} \mathrm{C}$. More research and experimental work is needed to completely analyze the heavy metal impact in biochar [56]. The microplastics are also removed at a temperature of $500{ }^{\circ} \mathrm{C}$, which decreases the potential risk to the environment [57]. The detailed mass balance is presented in the Table S2 in the Supplementary Materials.

The pyrolysis and combustion processes differ in their energy balance (Table 4). The production of district heat is the main product in combustion, whereas pyrolysis produces biochar, and the energy of the pyrolysis gas is used to heat the pyrolysis process and dry the sludge. The additional energy consumption in the reject water recovery scenario is 
due to the increased mass flow rate of the water, which needs to be heated up to $60{ }^{\circ} \mathrm{C}$ for stripping. Consequently, the stripper-scrubber electricity consumption is tripled as compared to the energy balance without reject water recovery. The condensate entering the stripper without reject water recovery has a temperature of $60{ }^{\circ} \mathrm{C}$ [50] and further heating is not required. However, with reject water recovery, the reject water is assumed to be $28{ }^{\circ} \mathrm{C}$ before heating because the temperature of the digested mass is usually $28-32{ }^{\circ} \mathrm{C}$ after dewatering; hence, the liquid needs to first be heated to $60{ }^{\circ} \mathrm{C}$ to achieve the optimum efficiency in the stripper [58].

Table 3. Comparison of mass balance for pyrolysis and combustion.

\begin{tabular}{lccc}
\hline Mass Balance & Pyrolysis & Combustion & Units \\
\hline Inputs & & & \\
Wastewater & $92,000,000$ & $92,000,000$ & $\mathrm{t} / \mathrm{a}$ \\
Wood waste & 27,000 & 27,000 & $\mathrm{t} / \mathrm{a}$ \\
$\mathrm{H}_{2} \mathrm{SO}_{4}$ & 3700 & 3700 & $\mathrm{t} / \mathrm{a}$ \\
$\mathrm{NaOH}$ & 3100 & 3100 & $\mathrm{t} / \mathrm{a}$ \\
Intermediate products & & & \\
Mass to digestion & 950,000 & 950,000 & $\mathrm{t} / \mathrm{a}$ \\
Biogas & 13,000 & 13,000 & $\mathrm{t} / \mathrm{a}$ \\
Reject water from mechanical dewatering & 867,000 & 867,000 & $\mathrm{t} / \mathrm{a}$ \\
Dewatered sludge & 65,000 & 65,000 & $\mathrm{t} / \mathrm{a}$ \\
Thermally dried sludge & 27,000 & 27,000 & $\mathrm{t} / \mathrm{a}$ \\
Outputs & & & \\
Clean water & $91,500,000$ & $91,500,000$ & $\mathrm{t} / \mathrm{a}$ \\
Ash & 0 & 9700 & $\mathrm{t} / \mathrm{a}$ \\
Biochar & 12,000 & 0 & $\mathrm{t} / \mathrm{a}$ \\
\hline
\end{tabular}

Comparing the end products, in addition to the respective biochar and district heat, both processes also produce $3500 \mathrm{t}$ of ammonium sulfate from the drying fumes and reject water (Table 5). The chemical consumption is also analyzed for both stripping and scrubbing. $\mathrm{NaOH}$ is used in the stripper to raise the $\mathrm{pH}$ of the liquid to $8-11$, depending on the process conditions, while $\mathrm{H}_{2} \mathrm{SO}_{4}$ is used as a scrubbing agent to absorb ammonium ions.

The concentration of ammonium sulfate affects how it can be used in agriculture in combination with other fertilizers. In order to achieve commercial-grade fertilizer, further post-treatment such as crystallization or evaporation may be required, which adds cost to the process [31].

\subsection{Comparison of Revenues and Costs}

The cost and revenue calculations were conducted for both process scenarios and with and without reject water recovery. Biochar and heat, having monetary value, are the main products of the two optional sludge treatment processes. Biochar can have commercial value, but it is subject to a wide range of prices depending on many factors, such as the source of the feedstock, process parameters, amount of equipment used, and operating costs [59]. As there is no difference in biochar production with or without reject water recovery, Table 6 presents different values from the literature to analyze the revenue generation in the pyrolysis scenarios S1.1 and S1.2. The other reasons for biochar's uncertain market value are the unavailability of commercial-scale production methods and the unestablished demand for different quality biochars. The high cost of biochar prevents consumers from using it in large quantities, but this cost will reduce following the commercial production of biochar. Furthermore, biochar made from biomass can be utilized in pyrogenic carbon capture and storage (PyCCS), whereby sequestered carbon dioxide can be sold on the market (Puro Earth 2021), which could offer added value for biochar made of sewage sludge digestate. 
Table 4. Comparison of energy balance for both pyrolysis and combustion with and without reject water recovery.

\begin{tabular}{lcc}
\hline Energy Balance & Pyrolysis (MWh/a) & Combustion (MWh/a) \\
\hline Without reject water & & \\
Consumption & -6500 & -9600 \\
Reactor electricity consumption & -680 & -680 \\
Stripper and scrubber electricity consumption & 0 & 56,000 \\
Production & 0 & 62,000 \\
District heat sewage sludge & 0 & 120,000 \\
District heat wood & -7200 & $-10,000$ \\
\hline Net balance of heat & & \\
Net balance of electricity & & -9600 \\
\hline With reject water & -6500 & -3900 \\
Consumption & -3900 & $-34,000$ \\
Reactor electricity consumption & $-34,000$ & 56,000 \\
Stripper and scrubber electricity consumption & & 62,000 \\
Stripper heat consumption & 0 & 84,000 \\
Production & 0 & $-13,000$ \\
District heat sewage sludge & $-34,000$ & \\
District heat wood & $-10,000$ & \\
\hline Net balance of heat & & \\
Net balance of electricity & &
\end{tabular}

Table 5. Production of ammonium sulfate.

\begin{tabular}{lccc}
\hline Ammonium Sulfate Production & Pyrolysis & Combustion & Units \\
\hline Ammonium sulfate $/ \mathrm{kg} \mathrm{NH}_{3}$ & 4 & 4 & $\mathrm{~kg}_{\text {ammsulfate }} / \mathrm{kg} \mathrm{NH}_{3}$ \\
Ammonium sulfate from total off-gases & 600 & 600 & $\mathrm{t}_{\text {ammsulfate }} \mathrm{a}$ \\
Ammonium sulfate (from reject water) & 2900 & 2900 & $\mathrm{t}_{\text {ammsulfate }} / \mathrm{a}$ \\
Total ammonium sulfate & 3500 & 3500 & $\mathrm{t}_{\text {ammsulfate }} / \mathrm{a}$ \\
\hline
\end{tabular}

As shown in Table 7, the commercial value of district heating produced in combustion is also compared with existing district heating prices, excluding VAT, for scenarios S2.1 and S2.2. The main difference between the two scenarios is the larger consumption of heat during reject water recovery, which is necessarily subtracted from the total production of district heat. District heating clearly has the potential to generate revenue. Moreover, the disposal cost of sewage sludge in landfill ranges between 60 and $200 \mathrm{EUR} / \mathrm{t}$ of TS in Europe. The treatment cost using pyrolysis and combustion may be higher, but these represent an environmentally safe way to utilize sewage sludge [60].

Table 6. Revenue and cost estimation of fertilizer and used chemicals for S1.1 and S1.2 (pyrolysis with nitrogen recovery).

\begin{tabular}{lcccc}
\hline Pyrolysis & & & Reference \\
\hline Costs & Mass, t/a & Cost, EUR/t & Total, M EUR/a & \\
Chemical used & & & & \\
$\mathrm{H}_{2} \mathrm{SO}_{4}$ & 3700 & 160 & -0.59 & {$[61]$} \\
$\mathrm{NaOH}$ & 3100 & 380 & -1.2 & {$[62]$} \\
Annual investment & & & & \\
Sewage sludge & 65,000 & $35-45$ & $-2.3-(-2.9)$ & {$[63]$} \\
Revenues & Mass, t/a & Price (EUR/t) & Total, (M EUR/a) & \\
Ammonium sulfate-N & 4000 & 660 & 2.6 & {$[51]$} \\
Biochar & 12,000 & 400 & 4.8 & {$[63]$} \\
\hline Total & & & $\mathbf{2 . 8 - 3 . 4}$ & \\
\hline
\end{tabular}


Table 7. Revenue and cost estimation of fertilizer and used chemicals for S2.1 and S2.2 (combustion with nitrogen recovery).

\begin{tabular}{|c|c|c|c|c|}
\hline Combustion & & & & Reference \\
\hline Costs & Mass, $\mathbf{t} / \mathbf{a}$ & Cost, EUR/t & Total, M EUR/a & \\
\hline Chemical used & & & & \\
\hline $\mathrm{H}_{2} \mathrm{SO}_{4}$ & 3700 & 160 & -0.59 & [61] \\
\hline $\mathrm{NaOH}$ & 3100 & 380 & -1.2 & [62] \\
\hline Annual investment & & & & \\
\hline Sewage sludge & 65,000 & $30-60$ & $-2-(-3.9)$ & [63] \\
\hline Revenues & Mass, $\mathbf{t} / \mathbf{a}$ & $\begin{array}{l}\text { Nitrogen/Phosphorus } \\
\text { (EUR/t) }\end{array}$ & Total, (M EUR/a) & \\
\hline $\begin{array}{l}\text { Ammonium } \\
\text { sulfate }\end{array}$ & 4000 & 660 & 2.6 & [51] \\
\hline Phosphorus & 480 & 1600 & 0.76 & [51] \\
\hline & MWh/a & Price (EUR/MWh) & Total, (M EUR/a) & \\
\hline District heat & 120,000 & 66 & 7.9 & [46-49] \\
\hline Total & & & $3.3-5.2$ & \\
\hline
\end{tabular}

The recovery of nitrogen from reject water increases the amount of ammonium sulfate produced. For both pyrolysis and combustion, Tables 6 and 7 show the revenue generated in terms of nitrogen (in the form of ammonium sulfate) and phosphorus. Ammonium sulfate can generate $3 \mathrm{M}$ EUR/a in revenue from both the pyrolysis and combustion processes, whereas phosphorus can generate $1 \mathrm{M}$ EUR/a in the combustion process. The reason for the high revenue from combustion is the ash produced in addition to district heating.

On the other hand, the recovery of reject water also increases the chemical consumption requirement in stripping and scrubbing. $\mathrm{H}_{2} \mathrm{SO}_{4}$ and $\mathrm{NaOH}$ each add $1 \mathrm{M}$ EUR/a to the operational cost.

The economic estimations of the scenarios can only be approximated since both technologies are in the pilot phase and there is no exact information on the investment and operation costs at the full scale. The total investment cost of the Rovaniemi plant is about $4.3 \mathrm{M}$ EUR, and taking the interest rate of $5 \%$ and a depreciation period of 20 years, the calculated investment cost is about $30 \mathrm{EUR} / \mathrm{t}$ of sludge treated. The fluidized bed combustion plants in Geneva, with a capacity of 55,000 t/a and 28\% TS, and the 90,000 t/a plant in Zurich, Switzerland, with 33\% TS, have total investment costs of 30-50 M EUR. In Finland, a large fluidized bed plant with a capacity of 70,000 t/a and 25\% TS costs about 25 M EUR. Similarly, a pyrolysis plant with the capacity of 30,000 t/a, assuming a $5 \%$ interest rate and a 20-year depreciation period, will have an investment cost of 13-17 M EUR, or 35-45 EUR/t of sludge treated [63].

In this study, $65,000 \mathrm{t} / \mathrm{a}$ of sludge with $29 \% \mathrm{TS}$ also falls within the range of the investment costs provided above. In Tables 6 and 7 , the estimated investment costs are presented for both the combustion and pyrolysis processes in the different pilot plants. These costs are comparable to the revenues and major chemical costs. The annual investment costs for combustion are 2-4 M EUR, whereas for pyrolysis they range between 2 and $3 \mathrm{M}$ EUR. Adding up the revenues for all the byproducts and subtracting the chemical costs for the reject water recovery scenario, the total revenue would be 3-5 M EUR/a and 3-3.5 M EUR/a for combustion and pyrolysis, respectively. In comparison with the annual investment cost, these revenue values clearly dominate. The two-edged benefits of sewage sludge include the recovery of nutrients from waste and the production of revenue from the resultant products, thereby emphasizing the need to consider these alternatives in sewage sludge management.

\section{Conclusions}

The integration of pyrolysis and combustion processes with a gas scrubbing technology at a large-scale WWTP was investigated through mass and energy balance calculations, in order to maximize the recovery of nutrients and energy from municipal sewage sludge. 
It is shown that approximately $73 \%$ (3600 t/a) of the total nitrogen within the wastewater entering the WWTP (4900 t/a) is lost to the air and clean water; the rest is divided between different stages of sludge treatment. Nitrogen can be recovered from two stages: (i) mechanical dewatering $(16 \%, 780 \mathrm{t} / \mathrm{a})$ and (ii) thermal drying $(3 \%, 270 \mathrm{t} / \mathrm{a})$. Furthermore, $120 \mathrm{GWh} / \mathrm{a}$ of district heat and $9700 \mathrm{t} / \mathrm{a}$ of ash with $500 \mathrm{t} / \mathrm{a}$ phosphorus are obtained in the combustion scenario and 12,000 t/a of biochar with $500 \mathrm{t} / \mathrm{a}$ phosphorus is obtained in the pyrolysis scenario.

It is not possible to recover a large amount of nitrogen from thermal drying alone, and investment for this purpose only would not be cost-effective. However, there is a likelihood that the ammonia in the off-gases of thermal drying is oxidized, producing NOx emissions, which would make the investment for nitrogen removal/recovery more desirable. The high nitrogen content in reject water can represent a high wastewater treatment cost for sludge treatment plants and a nitrogen load problem for WWTPs. In this regard, it would be beneficial to recover nitrogen from two sources instead of one, i.e., reject water and thermal drying fumes, as it would not substantially change the dimensions of the equipment required for recovery. The recovery from thermal drying fumes could be performed with almost the same effort and expense as the recovery from reject water alone, but the recovery rate would increase by more than $20 \%$.

The addition of a stripper and a scrubber for nitrogen recovery increases the total electricity consumption in both scenarios. Combustion and pyrolysis require annual investment costs of 2-4 M EUR/a and 2-3 M EUR/a, respectively, while 3-5 M EUR/a and 3-3.5 M EUR/a would be generated as product revenues.

Both technologies are viable options for nutrient and energy recovery during sewage sludge disposal, having the capability to overtake conventional sewage sludge disposal methods. However, further research is required for high product yields and decreased investment costs.

Supplementary Materials: The following are available online https:/ /www.mdpi.com/article/10.3 390/recycling6030052/s1, Table S1: Properties, Table S2: Detailed mass balance of WWTP, pyrolysis and combustion, Table S3: Calculations of energy balance for pyrolysis and combustion, Table S4: Nitrogen balance for combustion with and without reject water recovery, Table S5: Nitrogen balance for pyrolysis with and without reject water recovery, Table S6: Phosphorus balance for combustion and pyrolysis.

Author Contributions: Conceptualization, A.S., J.H. and M.H.; methodology, A.S.; validation, A.S. and J.H.; data curation, A.S., J.H. and P.P.; writing — original draft preparation, A.S.; writing-review and editing, J.H., P.P. and M.H.; visualization, A.S.; supervision, J.H. and M.H.; project administration, M.H. All authors have read and agreed to the published version of the manuscript.

Funding: This research was performed as part of the NITRO project co-financed by the Academy of Finland (decision number 315051).

Conflicts of Interest: The authors declare no conflict of interest.

\section{References}

1. United Nations World Population Prospects 2019: Highlights. Available online: https://www.un.org/development/desa/ publications/world-population-prospects-2019-highlights.html (accessed on 21 July 2020).

2. Zhang, L.; Xu, C.; Champagne, P.; Mabee, W. Overview of current biological and thermo-chemical treatment technologies for sustainable sludge management. Waste Manag. Res. 2014, 32, 586-600. [CrossRef]

3. Mateo-Sagasta, J.; Raschid-Sally, L.; Thebo, A. Global Wastewater and Sludge Production, Treatment and Use. In Wastewater: Economic Asset in an Urbanizing World; Drechsel, P., Qadir, M., Wichelns, D., Eds.; Springer: Dordrecht, The Netherlands, 2015; pp. 15-38. ISBN 978-94-017-9545-6.

4. Faria, W.M.; de Figueiredo, C.C.; Coser, T.R.; Vale, A.T.; Schneider, B.G. Is sewage sludge biochar capable of replacing inorganic fertilizers for corn production? Evidence from a two-year field experiment. Arch. Agron. Soil Sci. 2018, 64, 505-519. [CrossRef]

5. Fytili, D.; Zabaniotou, A. Utilization of sewage sludge in EU application of old and new methods-A review. Renew. Sustain. Energy Rev. 2008, 12, 116-140. [CrossRef]

6. Mahon, A.M.; O'Connell, B.; Healy, M.G.; O'Connor, I.; Officer, R.; Nash, R.; Morrison, L. Microplastics in sewage sludge: Effects of treatment. Environ. Sci. Technol. 2017, 51, 810-818. [CrossRef] 
7. Havukainen, J.; Nguyen, M.T.; Hermann, L.; Horttanainen, M.; Mikkilä, M.; Deviatkin, I.; Linnanen, L. Potential of phosphorus recovery from sewage sludge and manure ash by thermochemical treatment. Waste Manag. 2016, 49, 221-229. [CrossRef]

8. Bolzonella, D.; Fatone, F.; Gottardo, M.; Frison, N. Nutrients recovery from anaerobic digestate of agro-waste: Techno-economic assessment of full scale applications. J. Environ. Manag. 2018, 216, 111-119. [CrossRef]

9. Karri, R.R.; Sahu, J.N.; Chimmiri, V. Critical review of abatement of ammonia from wastewater. J. Mol. Liq. 2018, 261, 21-31. [CrossRef]

10. Chrispim, M.C.; Scholz, M.; Nolasco, M.A. Phosphorus recovery from municipal wastewater treatment: Critical review of challenges and opportunities for developing countries. J. Environ. Manag. 2019, 248, 109268. [CrossRef] [PubMed]

11. Ye, Y.; Ngo, H.H.; Guo, W.; Liu, Y.; Chang, S.W.; Nguyen, D.D.; Liang, H.; Wang, J. A critical review on ammonium recovery from wastewater for sustainable wastewater management. Bioresour. Technol. 2018, 268, 749-758. [CrossRef] [PubMed]

12. van der Hoek, J.; Duijff, R.; Reinstra, O. Nitrogen Recovery from Wastewater: Possibilities, Competition with Other Resources, and Adaptation Pathways. Sustainability 2018, 10, 4605. [CrossRef]

13. Beckinghausen, A.; Odlare, M.; Thorin, E.; Schwede, S. From removal to recovery: An evaluation of nitrogen recovery techniques from wastewater. Appl. Energy 2020, 263, 114616. [CrossRef]

14. Rockström, J.; Steffen, W.; Noone, K.; Persson, A.; Chapin, F.S.; Lambin, E.F.; Lenton, T.M.; Scheffer, M.; Folke, C.; Schellnhuber, H.J.; et al. A safe operating space for humanity. Nature 2009, 461, 472-475. [CrossRef] [PubMed]

15. Paredes, D.; Kuschk, P.; Mbwette, T.S.A.; Stange, F.; Müller, R.A.; Köser, H. New aspects of microbial nitrogen transformations in the context of wastewater treatment-A review. Eng. Life Sci. 2007, 7, 13-25. [CrossRef]

16. Kahiluoto, H.; Kuisma, M.; Kuokkanen, A.; Mikkilä, M.; Linnanen, L. Taking planetary nutrient boundaries seriously: Can we feed the people? Glob. Food Secur. 2014, 3, 16-21. [CrossRef]

17. Cottes, M.; Mainardis, M.; Goi, D.; Simeoni, P. Demand-Response Application in Wastewater Treatment Plants Using Compressed Air Storage System: A Modelling Approach. Energies 2020, 13, 4780. [CrossRef]

18. Cao, Y.; Pawłowski, A. Sewage sludge-to-energy approaches based on anaerobic digestion and pyrolysis: Brief overview and energy efficiency assessment. Renew. Sustain. Energy Rev. 2012, 16, 1657-1665. [CrossRef]

19. Cano, R.; Pérez-Elvira, S.I.; Fdz-Polanco, F. Energy feasibility study of sludge pretreatments: A review. Appl. Energy 2015, 149, 176-185. [CrossRef]

20. Fan, X.; Zhang, X. Adsorption properties of activated carbon from sewage sludge to alkaline-black. Mater. Lett. 2008, 62, 1704-1706. [CrossRef]

21. Leng, L.; Yuan, X.; Huang, H.; Shao, J.; Wang, H.; Chen, X.; Zeng, G. Bio-char derived from sewage sludge by liquefaction: Characterization and application for dye adsorption. Appl. Surf. Sci. 2015, 346, 223-231. [CrossRef]

22. Kumar, M.; Dutta, S.; You, S.; Luo, G.; Zhang, S.; Show, P.L.; Sawarkar, A.D.; Singh, L.; Tsang, D.C.W. A critical review on biochar for enhancing biogas production from anaerobic digestion of food waste and sludge. J. Clean. Prod. 2021, 305, 127143. [CrossRef]

23. Barry, D.; Barbiero, C.; Briens, C.; Berruti, F. Pyrolysis as an economical and ecological treatment option for municipal sewage sludge. Biomass Bioenergy 2019, 122, 472-480. [CrossRef]

24. Kan, T.; Strezov, V.; Evans, T.J. Lignocellulosic biomass pyrolysis: A review of product properties and effects of pyrolysis parameters. Renew. Sustain. Energy Rev. 2016, 57, 1126-1140. [CrossRef]

25. Syed-Hassan, S.S.A.; Wang, Y.; Hu, S.; Su, S.; Xiang, J. Thermochemical processing of sewage sludge to energy and fuel: Fundamentals, challenges and considerations. Renew. Sustain. Energy Rev. 2017, 80, 888-913. [CrossRef]

26. Schnell, M.; Horst, T.; Quicker, P. Thermal treatment of sewage sludge in Germany: A review. J. Environ. Manag. 2020, $263,110367$. [CrossRef]

27. Oladejo, J.; Shi, K.; Luo, X.; Yang, G.; Wu, T. A review of sludge-to-energy recovery methods. Energies 2019, 12, 60. [CrossRef]

28. Domínguez, A.; Menéndez, J.A.; Pis, J.J. Hydrogen rich fuel gas production from the pyrolysis of wet sewage sludge at high temperature. J. Anal. Appl. Pyrolysis 2006, 77, 127-132. [CrossRef]

29. Zhang, B.; Xiong, S.; Xiao, B.; Yu, D.; Jia, X. Mechanism of wet sewage sludge pyrolysis in a tubular furnace. Int. J. Hydrogen Energy 2011, 36, 355-363. [CrossRef]

30. Deviatkin, I.; Havukainen, J.; Horttanainen, M. Possibilities for enhanced nitrogen recovery from digestate through thermal drying. J. Mater. Cycles Waste Manag. 2018, 20, 1016-1025. [CrossRef]

31. Saud, A.; Havukainen, J.; Mänttäri, M.; Horttanainen, M. Evaluation and techno-economic analysis of packed bed scrubber for ammonia recovery from drying fumes produced during the thermal drying of sewage sludge. E3S Web Conf. 2020, 191, 03001. [CrossRef]

32. Wu, B.; Wang, H.; Wang, C.; Dai, X.; Chai, X. Environmentally-friendly dewatering of sewage sludge: A novel strategy based on amphiphilic phase-transfer induced by recoverable organic solvent. Chem. Eng. J. 2021, 409, 128212. [CrossRef]

33. Kätkä, K.; Laboratory Testing Methods for Centrifugal Sludge Dewatering Processes. Tampere University of Applied Sciences. 2013. Available online: http:/ / urn.fi/URN:NBN:fi:amk-2013060212355 (accessed on 28 July 2021).

34. Guo, C.H.; Stabnikov, V.; Ivanov, V. The removal of nitrogen and phosphorus from reject water of municipal wastewater treatment plant using ferric and nitrate bioreductions. Bioresour. Technol. 2010, 101, 3992-3999. [CrossRef]

35. Helsinki Region Environmental Services (HSY). Jätevedenpuhdistus Pääkaupunkiseudulla 2018: Viikinmäen ja Suomenojan Jätevedenpuhdistamo [in Finnish]. 2019. Available online: https://julkaisu.hsy.fi/jatevedenpuhdistus-paakaupunkiseudulla-20 18.pdf (accessed on 28 July 2021). 
36. Durdevic, D.; Blecich, P.; Juric, Z. Energy Recovery from Sewage Sludge: The Case Study of Croatia. Energies 2019, $12,1927$. [CrossRef]

37. Horttanainen, M.; Deviatkin, I.; Havukainen, J. Nitrogen release from mechanically dewatered sewage sludge during thermal drying and potential for recovery. J. Clean. Prod. 2017, 142, 1819-1826. [CrossRef]

38. Ghyselbrecht, K.; Monballiu, A.; Somers, M.H.; Sigurnjak, I.; Meers, E.; Appels, L.; Meesschaert, B. Stripping and scrubbing of ammonium using common fractionating columns to prove ammonium inhibition during anaerobic digestion. Int. J. Energy Environ. Eng. 2018, 9, 447-455. [CrossRef]

39. Vaneeckhaute, C.; Lebuf, V.; Michels, E.; Belia, E.; Vanrolleghem, P.A.; Tack, F.M.G.; Meers, E. Nutrient Recovery from Digestate: Systematic Technology Review and Product Classification. Waste Biomass Valorization 2017, 8, 21-40. [CrossRef]

40. Khakharia, P.; Huizinga, A.; Jurado Lopez, C.; Sanchez Sanchez, C.; de Miguel Mercader, F.; Vlugt, T.J.H.; Goetheer, E. Acid Wash Scrubbing as a Countermeasure for Ammonia Emissions from a Postcombustion $\mathrm{CO}_{2}$ Capture Plant. Ind. Eng. Chem. Res. 2014, 53, 13195-13204. [CrossRef]

41. Melse, R.W.; Ogink, N.W.M. Air scrubbing techniques for ammonia and odor reduction at livestock operations: Review of on-farm research in the netherlands. Trans. ASAE 2005, 48, 2303-2313. [CrossRef]

42. Hadlocon, L.J.S.; Manuzon, R.B.; Zhao, L. Development and evaluation of a full-scale spray scrubber for ammonia recovery and production of nitrogen fertilizer at poultry facilities. Environ. Technol. 2015, 36, 405-416. [CrossRef]

43. Suutari, M.; (Carbons Oy, Kouvola, Finland). Personal communication, 2021.

44. Varpula, V. Biohiilen Mahdollisuudet Kasvihuonekaasupäästöken Kompensoinnissa [In Finnish]. Lappeenranta University of Technology. 2020. Available online: http:/ / urn.fi/URN:NBN:fi-fe2020101383960 (accessed on 28 July 2021).

45. Austin, A. Beyond the Hype. Biomassmagazine.com. Available online: http://biomassmagazine.com/articles/4080/beyond-the--hype (accessed on 11 July 2021).

46. Hakala, K. District Heating Prices Go Wild in Finland. Natural Resources Insitute of Finland (LUKE). 2016. Available online: https:/ / www.luke.fi/en/blog/district-heating-prices-go-wild-in-finland/ (accessed on 28 July 2021).

47. Helen Ltd. District Heat Prices. Available online: https://www.helen.fi/en/heating-and-cooling/district-heat/district-heatprices (accessed on 11 July 2021).

48. Motiva Ltd. District Heat Prices. Available online: https://www.motiva.fi/koti_ja_asuminen/rakentaminen/lammitysjarjestelman valinta/lammitysmuodot/kaukolampo/kaukolammon_hinta (accessed on 25 March 2021).

49. Helsinki Region Environmental Services (HSY). Energy and Material Balances and Greenhouse Gas Emissions of Helsinki Region Environmental Services (HSY). Available online: https:/ / hri.fi/data/dataset/helsingin-seudun-ymparistopalvelujen-hsy-energia-jamateriaalitaseet-seka-kasvihuonekaasupaastot/resource/538fc945-7b9e-44a7-b899-a22967270ed5 (accessed on 25 March 2021).

50. Endev Ltd. Internal report: Air Emissions from Rovaniemi Pilot Plant. 2020.

51. Havukainen, J.; Uusitalo, V.; Koistinen, K.; Liikanen, M.; Horttanainen, M. Carbon footprint evaluation of biofertilizers. Int. J. Sustain. Dev. Plan. 2018, 13, 1050-1060. [CrossRef]

52. Donatello, S.; Cheeseman, C.R. Recycling and recovery routes for incinerated sewage sludge ash (ISSA): A review. Waste Manag. 2013, 33, 2328-2340. [CrossRef]

53. Zielińska, A.; Oleszczuk, P. Evaluation of sewage sludge and slow pyrolyzed sewage sludge-derived biochar for adsorption of phenanthrene and pyrene. Bioresour. Technol. 2015, 192, 618-626. [CrossRef]

54. Brassard, P.; Godbout, S.; Lévesque, V.; Palacios, J.H.; Raghavan, V.; Ahmed, A.; Hogue, R.; Jeanne, T.; Verma, M. Biochar for soil amendment. In Char and Carbon Materials Derived from Biomass: Production, Characterization and Applications; Elsevier: Amsterdam, The Netherlands, 2019; pp. 109-146. ISBN 9780128148945.

55. Gopinath, A.; Divyapriya, G.; Srivastava, V.; Laiju, A.R.; Nidheesh, P.V.; Kumar, M.S. Conversion of sewage sludge into biochar: A potential resource in water and wastewater treatment. Environ. Res. 2021, 194, 110656. [CrossRef]

56. Li, B.; Ding, S.; Fan, H.; Ren, Y. Experimental Investigation into the Effect of Pyrolysis on Chemical Forms of Heavy Metals in Sewage Sludge Biochar (SSB), with Brief Ecological Risk Assessment. Materials 2021, 14, 447. [CrossRef] [PubMed]

57. Ni, B.-J.; Zhu, Z.-R.; Li, W.-H.; Yan, X.; Wei, W.; Xu, Q.; Xia, Z.; Dai, X.; Sun, J. Microplastics Mitigation in Sewage Sludge through Pyrolysis: The Role of Pyrolysis Temperature. Environ. Sci. Technol. Lett. 2020, 7, 961-967. [CrossRef]

58. Arnold, E.; Böhm, B.; Wilderer, P.A. Application of activated sludge and biofilm sequencing batch reactor technology to treat reject water from sludge dewatering systems: A comparison. Water Sci. Technol. 2000, 41, 115-122. [CrossRef]

59. Ahmed, M.B.; Zhou, J.L.; Ngo, H.H.; Guo, W.; Chen, M. Progress in the preparation and application of modified biochar for improved contaminant removal from water and wastewater. Bioresour. Technol. 2016, 214, 836-851. [CrossRef] [PubMed]

60. European Commission. Disposal and Recycling Routes for Sewage Sludge Part 4Economic Report. 2002. Available online: https:/ / ec.europa.eu/environment/archives/waste/sludge/pdf/sludge_disposal4.pdf (accessed on 28 July 2021).

61. Corporation Ltd. Sulfuric Acid Prices. Available online: https://www.alibaba.com/product-detail/sulfuric-acid-98-_5003919429 5.html?spm=a2700.galleryofferlist.normal_offer.d_title.115569e017c7zS (accessed on 11 July 2021).

62. Shandong New Power Co., Ltd. Biochar Prices. Available online: https://www.alibaba.com/showroom/biochar+.html?fsb=y\& IndexArea=product_en\&CatId=\&SearchText=biochar+\&isGalleryList=G (accessed on 25 March 2021).

63. Vesilaitosyhdistys. Puhdistamolietteen Termiset Käsittelymenetelmät ja Niiden Soveltuvuus Suomeen. 2019. (In Finnish). Available online: https://www.vvy.fi/site/assets/files/2916/puhdistamolietteen_termiset_kasittelymenetelmat_ja_niiden_ soveltuvuus_suomeen.pdf (accessed on 28 July 2021). 